\title{
Identification of e-HRM Practices in Egypt Five-star Hotels: A Quantitative Approach
}

\author{
Mohamed Omar Ahmed \\ Faculty of Tourism and Hotels-Fayoum University
}

\begin{abstract}
This paper aims to identify the effect of e-HRM practices on hotel performance by measuring HRM service quality and employee productivity in Five-star hotels in Cairo. This study used a quantitative research approach. Data was collected through questionnaires from 25 Five-star hotels in Cairo selected to be the sampling frame. A convenience sample technique was chosen in this research to collect data using administrated questionnaire to $\mathrm{HR}$ managers, $\mathrm{HR}$ supervisors and HR employees. The total number of distributed questionnaires was 500 copies out of which only 350 have been returned. The general response rate was $70 \%$. SPSS (Version, 26) software was used for analysis data.

The results showed the importance and benefits of e-HRM application in Five-star hotels in Egypt. The results explain the agreement of the participants for e-HRM practices in five-star hotels. Additionally, the findings highlight the importance of e-HRM practices, which include operational, relational and transformational. The aforementioned practices help to improve the human resources service's quality and employee productivity, which in turn will lead to an improvement in the hotel's performance. This current study contributes to the theory by enriches the existing literature on e-HRM and it showed that importance of e-HRM application in hotels. However, the current study has some limitations. Firstly, this paper concentrates on a specific category of hotels (Five-star hotels). Secondly, the research focuses on a specific geographical location, Cairo. Therefore, future research should address more hotels in Egypt.
\end{abstract}

Keywords: e-HRM, HRM Service Quality, Employee Productivity, Hotel Performance.

\section{Introduction}

Today, the hospitality industry is rapidly developing in the 2019). The development of human resources is considered a critical factor for the success of the hotel industry (Iqbal et al., 2019). Its success has increased the demand for service quality. Currently, the main challenge encountered by the hotel industry is demand for skilled human resources. In this impressive industry, the efficient use of hotel human resources will help improve the competitive advantage in the hotel market. Bagri et al. (2010) reported that hotels should improve and develop their human resources practices such as: recruit, select and train the staff in order to improve the service quality and achieve the hotel objectives. Moreover, the hotels seek to select skilled and qualified staff before entering the hotel field (Francis and Baum, 2018).

Consequently, the function of Human Resources Management (HRM) is considered the most important aspects of the hotel industry (Pandey and Kumar, 2017). For that, the majority of hospitality sectors are seeking to attract and develop the quality of their staff (Francis and Baum, 2018). As Nagpal, (2008) argued, the important role of human resources contributes with valuable points to the administration level. On the other hand, the department of human resources in the hospitality sectors starts to use IT in HR duties and functions (Mahfod and Khalifa, 2017). e-HRM practices seek to improve the function of HR that help to reduce costs and create a competitive advantage for the hotel industry (Foiji et al., 2019). e-HRM refers to the implementation the information technology (IT) in the practices and policies of HRM in the hotel industry, which in turn leads to increases in the effectiveness of HRM (Ruel et al., 2007, OlivasLujan et al., 2007).

Furthermore, e-HRM has attracted the attention of the researchers and human resource journals for publishing articles in this field (Agarwal and Lenka, 2018). Moreover, the literature shows 
that there is still little research on measuring the effect e-HRM practices on the organization performance, for instance tourism and hotel industry (Ali, 2017; Morsy and El Demerdash, 2017; Foiji et al., 2019). Therefore, this paper aims to identify the effect of e-HRM practices on hotel performance by measuring the HRM service quality and employee productivity in Five-star hotels in Cairo.

\section{Literature review \\ e-HRM definition and consequences}

Recently, information technology has been playing a critical role in human resources practices (Marler and Parry, 2016). This refers to implementation of the internet applications in all human resources process such as: selection, recruitment, training, planning, compensation, reward, and performance appraisal (Foiji et al., 2019). The success of the hotel industry depends on the skills and qualification of their human resources (Morsy and El Demerdash, 2017). For that, the hospitality seeks to use the new application of information technology to remain in the competitiveness (Marler and Parry, 2016). As a result, e-HRM has considered the new application based on internet and information technology ( $\operatorname{Rad}$ and Kim, 2018). The study of Morsy and El Demerdash, (2017) reported that there are several reasons for using the e-HRM in hospitality sectors, such as: the complexity of HR process and need to learn. Therefore, the hotels have tried to identify the importance of using information technology in human resources management (Yusoff et al., 2010). In addition, the literature stated that the concept of electronic human resource management (e-HRM) was first to be used in the late 1990s (Olivas-Lujan et al., 2007; Agarwal and Lenka, 2018).

Furthermore, Sareen and Subramanian, (2012) highlighted the difficulty to find a simple definition for e-HRM, as the concept of e-HRM depends on the application of information technology for managing the HR data. Moreover, it describes the system as an umbrella covering the HR activities and the operation of information technology. The study of Yusoff et al. (2010) suggested that e-HRM is the interchangeable process between web-site technology and computer-based on the practices of HRM. On the other hand, Morsy and El Demerdash, (2017) defined the e-HRM as an integrated process including the application of information technology on human resources managements which are accessible for manager, supervisors and employee at any time wanted (Al-Ajlouni et al., 2019). To sum up, e-HRM is the process of planning and implementing information technology on the activities of human resources (Bagri et al., 2010). The study of Foiji et al. (2019) mentioned that e-HRM helps the hotel industry to improve their service quality and develop HR activities by improving the following processes: recruitment, selection, orientation, training, and performance appraisal. This also brings several benefits for the hospitality sectors, such as: reducing and eliminating the HR costs (e.g. selecting and training), building IT systems for HRM, supporting training and empowerment process and perform the HR tasks quickly and effectively (Stone et al., 2013; Al Mamun and Islam, 2016).

Consequently, the practices of e-HRM help to improve employee qualify and competences reduce costs of staffing (Sareen and Subramanian, 2012). On the other hand, e-HRM enhances the communication between the employee and the customer and enhances the workflow (Francis and Baum, 2018). Additionally, e-HRM implementations that help the hotel industry to improve their reputation and achieve a competitive advantage (Choochote and Chochiang, 2015). Also, eHRM provides opportunities for automated HR tasks (Al Hrou and Mohamed, 2014; Ali, 2017).

\section{e-HRM practices}

e-HRM is considered a specific method for managing HRM activities which can be divided into three pillars: operational e-HRM, relational e-HRM and transformational e-HRM (Iqbal et al., 2019). Furthermore, e-HRM practices (operational, relational, and transformational) are 
dependent on several aspects including: e-recruitment, e-selecting, e-training, e-attendance, epayroll and e-planning (Bissola and Imperatori, 2013; Rajalakshmi and Gomathi, 2016; Iqbal et al., 2019). On the other hand, several authors highlighted these practices of e-HRM as below:

Firstly, operational e-HRM practices are considered the first process in e-HRM practices that refers to the basics of human resources activities at the administrative, it is also called zero levels. In other words, it refers to all process related to salary management, payroll and the database of HR employees (Sareen and Subramanian, 2012; Chuang and Lin, 2017).

Secondly, relational e-HRM practice is considered a tool to manage the relationship between the organization and the employee. This process seeks to support the practices of HRM such as: recruitment, selecting, training, reward and performance management (Morsy and El Demerdash, 2017).

Thirdly, transformational e-HRM practice refers to the practices of e-HRM that are matching with the employee's behavior and attitude such as: knowledge and strategic management (Iqbal et al., 2019).

\section{e-HRM practices and HRM services quality}

Iqbal et al. (2019) argued that several researchers have investigated the quality of human resources. e-HRM practice helps the hotel industry to deliver a high standard of service quality to the customer, without mistakes (Wahyudi and Park, 2014). It also assists the employee focus on their duties, which lead to a positive effect on the employee's productivity. Furthermore, Ramezen et al. (2013) argued that there is a direct relationship between e-HRM and the quality of human resources services. This matched with the study of Iqbal et al. (2019) and Foiji et al. (2019) highlighted that e-HRM practices are increasing the quality of HR services. On the other hand, Pandey and Kumar, (2017) claimed in their research that e-HRM is considered a critical process in the hotel industry and plays an important role in enhancing the service quality of HR by providing a suitable climate and environmental workplace.

Moreover, hotel industry seeks to improve and provide the high quality of HRM services, which requires implementing the operational, relational, and transformational of e-HRM practices.

\section{e-HRM practices and employee productivity}

The application of information technology aims to improve and increase the employee's qualification in the field (Iqbal et al., 2019). For that, the hotel industry seeks to use and implement e-HRM for developing the employee's efficiency (Marler and Parry, 2016). Additionally, the technology based on the management system provides opportunities for HR to enhance their activities and achieve the organization goals (Ahmad and Allen, 2015). According to, L'Écuyer et al. (2019) operational e-HRM practices helps to enhance the efficiency of HRM by enhancing the HR activities and reducing costs. In contrast, the study of Choochote and Chochiang, (2015) sustained that an improvement in the overall efficiency can be achieved by reducing the costs and time to perform different tasks (Rad and Kim, 2018).

The literature review mentioned that a relational e-HRM practice is a necessary process to build a positive cooperation between the organization and their employees (Iqbal et al., 2019). As a result of the new e-HRM methods based on supporting the inter-personal relationship within the organization (Chuang and Lin, 2017), the employee's abilities and qualifications desired for that role were directly impacted (Bissola and Imperatori, 2013). Additionally, transformational eHRM practices depend on different practices, for instance: management of knowledge, human resources planning and talent management (Sareen and Subramanian, 2012). These practices and activities lead to the employee's development and improve their efficiency (Iqbal et al., 2019). 


\section{e-HRM practices and hotel performance}

As noted in the literature review, the main aim of e-HRM is to improve the organization performance by enhancing HR service quality, reducing costs, improving the decision making and reducing unnecessary activities. These aspects affect directly on the employee's qualifications and skills (Morsy and El Demerdash, 2017). Similarity, Yusoff et al. (2010) reported that e-HRM is considered a new phenomenon, which seeks to improve the quality and performance of HR. As well, the adaptation of e-HRM in tourism and hotel industry, will increase the effectiveness of HRM practices and performance (Morsy and El Demerdash, 2017; Pandey and Kumar, 2017). As aforementioned, the literature review confirmed that the e-HRM practices (operational, relational and transformational) have a positive effect on both the quality HRM service and employee's productivity. Ultimately, this leads to the overall improvement of the hotel performance.

\section{Conceptual framework and hypotheses development}

The research framework aims to explain the study variables (see Figure 1), by illustrating the eHRM practices (operational, relational and transformational). The framework showed that there is a relationship between e-HRM practices and the quality service of HRM. As well as it highlights the relationship between e-HRM and employee productivity. Finally, the framework indicates that e-HRM plays an important role in improving the quality of HRM service and increasing employee productivity, which leads to an improvement in the hotel performance. Consequently, there is a relationship between e-HRM practices and the quality of HRM services/the employee's productivity, which directly affect the performance and workplace outcomes. The aforementioned explanations serve as a literature base, much needed in order to complete this research and test the following hypotheses:

- H1: There are statistically significant effects of operational e-HRM practices on HRM service quality.

- $\quad \mathrm{H} 2$ : There are statistically significant effects of relational e-HRM practices on HRM service quality.

H3: There are statistically significant effects of transformational e-HRM practices on HRM service quality.

- H4: There are statistically significant effects of operational e-HRM practices on employee productivity.

H5: There are statistically significant effects of relational e-HRM practices on employee productivity.

- $\quad$ H6: There are statistically significant effects of transformational e-HRM practices on employee productivity.

- H7: There are statistically significant effects of HRM service quality and employee productivity on hotel performance.

Figure 1: Conceptual framework of e-HRM practices in hotels

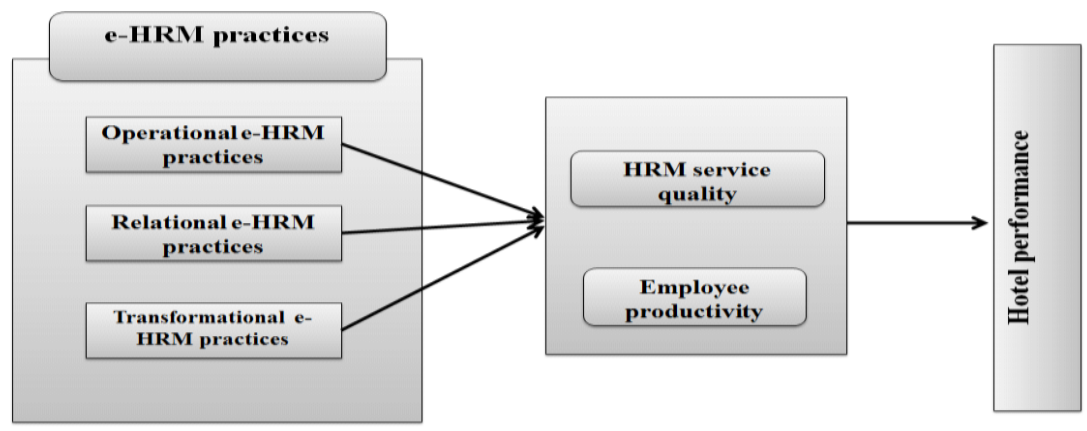




\section{Methodology}

This research aims to identify the effect of e-HRM practices on hotel performance by measuring HRM service quality and employee productivity in Five-star hotels in Cairo. Sample of 25 Fivestar hotels in Cairo selected to be the sampling frame (EHA, 2019). Cairo hotels were chosen due to their geographical convenience for the researcher and the researcher has access to these hotels. The reason for selected five-star hotels because it delivers a unique hospitality service in Egypt and due to its well-known reputation. The data collection uses primary and secondary data to achieve the research goal. Firstly, this research presents the process of gathering secondary data. Secondly, the primary data has been obtained with the use of questionnaire. This process took place in May and August 2019. Participants were offered the opportunities to take part in the study by filling in a questionnaire. The applicants had the options of answering the questions electronically (via email) or by hand.

The questionnaire comprised 7 questions and takes approximately 15 minutes to be completed. Before taking part in the questionnaire, participants were informed of their right to withdraw at any time. Also, it was highlighted that taking the test it is not compulsory, but very much appreciated. A piloting study was conducted among 10 participants to ensure the initial survey reliability and to explore any potential misunderstanding among respondents related to the items wording or survey length. The questionnaire involved six sections: respondents' demographic profiles, the concept of e-HRM, e-HRM practices in hotels (13 items), e-HRM and HRM service quality (5 items), e-HRM and employee productivity (6 items) and the effect of e-HRM on the hotel performance. The questionnaire items were modified from Iqbal et al. (2019). A five point of Likert scale ((1) Strongly Disagree, (2) Disagree, (3) Neutral, (4) Agree, (5) Strongly Agree), was used for e-HRM practices, e-HRM and HRM service quality and e-HRM and HRM service quality questions. A convenience sampling technique was chosen for data collection. 500 copies of questionnaire were given to HR managers, HR supervisors and HR employees. The final returned questionnaires were 350 copies with $70 \%$ response rate.

Questionnaire analysis was performed. Firstly, as recommended by Saunders et al, (2012), an initial screening of the data was done, descriptive analysis, and analyzing the hypothesis. The descriptive data involves percentages, frequencies and means calculations. Reliability analysis using Cronbach's Alpha and multiple regressions was used to test the effect of e-HRM practices (operational, relational, and transformational) on HRM service quality and employee productivity. This leads to a direct effect on hotel performance. SPSS (Version, 26) software was used for analysis data.

\section{Results and discussions \\ Descriptive analysis}

Table 1 indicated sample characteristics. The total number of fully completed surveys was 350 . The majority of the respondents were male $270(77.2 \%)$ and $80(22.8 \%)$ of the respondents were female. It was found that $175(50 \%)$ of the respondents' age was between 26-35years, 95 (27\%) of the respondents were $15-25$ years and the lowest percentage respondents $16 \%$ respectively $7 \%$ were between 36-45 year, respectively 46-55years respectively. In terms of work experience, the results shows $228(65 \%)$ of the respondents have worked between 6-10 years, $70(20 \%)$ of the respondents between 5 years or less and 52(15\%) of the respondents more than 11 years.

Table 1: Descriptive statistics of the sample $(\mathrm{N}=350)$

\begin{tabular}{|c|c|c|}
\hline Sample characteristics & Frequency & Percentage \\
\hline Gender & & \\
\hline Male & 270 & 77.2 \\
\hline Female & 80 & 22.8 \\
\hline
\end{tabular}


International Journal of Heritage, Tourism and Hospitality Vol. (14), No. (1), June, 2020

\begin{tabular}{|l|c|c|}
\hline \multicolumn{1}{|c|}{ Sample characteristics } & Frequency & Percentage \\
\hline Age & 95 & 27 \\
\hline $15-25$ & 175 & 50 \\
\hline $26-35$ & 55 & 16 \\
\hline $36-45$ & 25 & 7 \\
\hline $46-55$ & - & - \\
\hline More than 56 & \multicolumn{2}{|c|}{} \\
\hline \multicolumn{1}{|l|}{ Experience } & 70 & 20 \\
\hline 5 year or less & 228 & 65 \\
\hline 6-10 years & 52 & 15 \\
\hline More than 11 years & & \\
\hline
\end{tabular}

\section{The concept of e-HRM}

This section in questionnaire used to collect information related the concept of e-HRM. The results showed that 275(78.6\%) of the participants selected the right concept of e-HRM, while 75 (21.4\%) of the participants didn't select the right concept of e-HRM, see Table 2. This results matches Yusoff et al. (2010), claiming that e-HRM is the interchangeable process between website technology and computer-based on the practices of HRM. Morsy and El Demerdash, (2017) defined the e-HRM as the integrated process including the application of information technology on human resources management. Moreover, Sareen and Subramanian, (2012) highlighted that there is a difficulty to find a simple definition for e-HRM.

Table 2: The respondent's awareness about e-HRM concept

\begin{tabular}{|l|c|c|}
\hline \multicolumn{1}{|c|}{ Variables } & Frequency & Percentage \\
\hline $\begin{array}{l}\text { e-HRM is the interchangeable process only between website and } \\
\text { information technology. }\end{array}$ & 275 & 78.6 \\
\hline $\begin{array}{l}\text { e-HRM is the integrated process includes the application of information } \\
\text { technology on human resources management. It also, the process of } \\
\text { planning and implementing information technology on the activities of } \\
\text { human resources. }\end{array}$ & 75 & 21.4 \\
\hline
\end{tabular}

\section{e-HRM practices in hotel}

The results (in table 3) indicated that Cronbach's coefficients for e-HRM practices variables obtained from the questionnaires ranged from 0.77 of the transformational e-HRM variables to 0.86 of the operational e-HRM variables, which reflect the reliability of the questionnaire variables. The following table suggested that the mean scores for e-HRM practices in hotels ranged from 3.75 to 4.27 . The standard deviations for the items measuring it ranged between 0.75 to 0.96 displays a reasonable level of variability. The results reported that the grand mean of eHRM variables was 4.03 , which means the most common answer was being closed to value (4) or agree. These mean statistics explained the agreement of the participants for e-HRM practices in hotels. These results matched the existing literature on the topic. e-HRM is regarded by many researchers as a specific method for managing HRM activities, which divided into three pillars include: operational, relational, and transformational (Chuang and Lin, 2017; Mahfod and Khalifa, 2017; Iqbal et al., 2019).

Table 3: e-HRM practices in hotel

\begin{tabular}{|l|c|c|c|}
\hline \multicolumn{1}{|c|}{ e-HRM practices in hotel } & Mean & Std. Deviation & $\boldsymbol{\alpha}$ \\
\hline Operational e-HRM & & & \\
\hline - e-HRM is used for the daily administrative duties in the & 4.10 & 0.82 & 0.86 \\
\hline
\end{tabular}




\begin{tabular}{|c|c|c|c|}
\hline e-HRM practices in hotel & Mean & Std. Deviation & $\alpha$ \\
\hline \multicolumn{4}{|l|}{ hotel. } \\
\hline e-HRM is used in my hotel for schedules and attendance. & 4.00 & 0.79 & \\
\hline Managers use e-HRM to manage employee benefits. & 3.95 & 0.94 & \\
\hline $\begin{array}{l}\text { A sufficient number of training courses were offered to learn } \\
\text { how to work with the application of e-HRM. }\end{array}$ & 3.88 & 0.89 & \\
\hline \multicolumn{4}{|l|}{ Relational e-HRM } \\
\hline e-HRM is used to evaluate the staff at the hotel. & 4.13 & 0.77 & \multirow[t]{5}{*}{0.81} \\
\hline e-HRM is used to review the performance of the employee. & 4.05 & 0.96 & \\
\hline We use e-HRM for recruitment $\&$ selection processes. & 4.25 & 0.78 & \\
\hline $\begin{array}{l}\text { I would like to use e-HRM for grievances and official } \\
\text { complaints. }\end{array}$ & 3.75 & 0.91 & \\
\hline I would prefer to use e-HRM for online testing and learning. & 3.89 & 0.80 & \\
\hline \multicolumn{4}{|l|}{ Transformational e-HRM } \\
\hline $\begin{array}{l}\text { e-HRM is used to access information about the latest updates in } \\
\text { the hotel. }\end{array}$ & 4.18 & 0.75 & \multirow[t]{5}{*}{0.77} \\
\hline $\begin{array}{l}\text { Managers use e-HRM to receive official information on a wide } \\
\text { range of issues related to the hotel process. }\end{array}$ & 4.03 & 0.86 & \\
\hline Managers use e-HRM for talent management. & 3.93 & 0.76 & \\
\hline Manager encourages me to use the e-HRM application. & 4.27 & 0.94 & \\
\hline Total statistics of all variables & 4.03 & 0.98 & \\
\hline
\end{tabular}

Note: $\alpha$ : Cronbach's Alpha Coefficient

\section{e-HRM practices and HRM services quality}

In order to identify the effects of e-HRM practices on HRM service quality Table 4 showed that Cronbach's coefficients of HRM service quality variables obtained from the questionnaire were 0.88 , which reflects the reliability of the questionnaire. It also shows that the mean scores for eHRM and HRM service quality ranged from 3.87 to 4.30. The standard deviations for these items ranged between 0.88 and 1.02, displaying a reasonable level of variability. The results showed that the grand mean of e-HRM and HRM service quality variables were 4.10 , which they are situated between the choice value (4) agree and (5) strongly agree and it is closer to the choice value (4) or agree. These mean statistics show the satisfaction of the participants for e-HRM and HRM service quality. These results matched with the study of Ramezen et al. (2013) that there is a direct relationship between e-HRM and the quality of human resources services. Also, Foiji et al. (2019) explained that using e-HRM is considered the main indicator of the quality of human resources services. Similarity, the study of Iqbal et al. (2019) explains e-HRM practices will increase the quality of HR services. Furthermore, Pandey and Kumar (2017) mentioned that eHRM is considered a critical process in the hotel industry and plays an important role in enhancing the service quality of HR by providing a suitable workplace climate and environment.

Table 4: e-HRM practices and HRM service quality

\begin{tabular}{|l|c|c|c|}
\hline \multicolumn{1}{|c|}{ e-HRM practices and quality of service } & Mean & Std. Deviation & $\boldsymbol{\alpha}$ \\
\hline e-HRM ensures error-free management. & 3.87 & 0.88 & 0.88 \\
\cline { 1 - 3 } $\begin{array}{l}\text { e-HRM provides quality services to its internal customers (such as } \\
\text { managers and employees). }\end{array}$ & 4.03 & 1.02 & \\
\cline { 1 - 3 } Using e-HRM gives me more control over my work & 4.30 & 0.93 & \\
\hline
\end{tabular}




\begin{tabular}{|c|c|c|c|}
\hline e-HRM practices and quality of service & Mean & Std. Deviation & $\boldsymbol{\alpha}$ \\
\hline Using e-HRM improves the quality of the work I do. & 4.22 & 0.76 & 0.93 \\
\hline Our hotel HR services have been simplified and standardized. & 4.09 & 0.89 & \\
\hline Total statistics of all variables & 4.10 & 0.9 \\
\hline
\end{tabular}

Note: $\alpha$ : Cronbach's Alpha Coefficient

e-HRM practices and employee productivity

Table 5 presented the Mean, Standard deviation and Cronbach's coefficients of e-HRM and employee productivity. The Cronbach's coefficient for employee productivity variables is 0.82 , which refers to the reliability of the questionnaire. The following table also shows the mean scores for employee productivity ranged from 3.89 to 4.17. The standard deviations for these items ranged between 0.55 and 0.75 , displaying a reasonable level of variability. The results reported that the grand mean employee productivity scores were 4.04, which means the most common answer was being closed to value (4). These mean statistics suggest the agreement of the participants for the items referring employee productivity.

According to Iqbal et al. (2019) the application of information technology aimed to improve and increase employee productivity. Additionally, the technology based on the management system provides opportunities for HR to enhance their activities and achieve the organizations goals (Ahmad and Allen, 2015). For that, the current study's results are consistent with the literature review, which highlighted that e-HRM improve employee productivity.

Table 5: e-HRM practices and employee productivity

\begin{tabular}{|c|c|c|c|}
\hline e-HRM practices and employee productivity & Mean & Std. Deviation & $\alpha$ \\
\hline $\begin{array}{l}\text { e-HRM has increased the focus of managers and employees on their } \\
\text { core duties. }\end{array}$ & 4.05 & 0.68 & \multirow[t]{7}{*}{0.82} \\
\hline I think our employees' productivity is better than our competitors. & 4.17 & 0.55 & \\
\hline Using e-HRM, the effective average hour's loss decreased. & 3.89 & 0.75 & \\
\hline $\begin{array}{l}\text { Since the implementation of e-HRM, the average absentee rates have } \\
\text { decreased. }\end{array}$ & 4.09 & .730 & \\
\hline $\begin{array}{l}\text { e-HRM has increased the focus of managers and employees on their } \\
\text { core duties. }\end{array}$ & 3.97 & 0.65 & \\
\hline Using the e-HRM application name enhances my productivity. & 4.11 & 0.60 & \\
\hline Total statistics of all variables & 4.04 & 0.74 & \\
\hline
\end{tabular}

Note: $\alpha$ : Cronbach's Alpha Coefficient

\section{e-HRM practices and hotel performance}

In this part of the questionnaire the participants were asked: Does e-HRM practices affect hotel performance by improving HRM service quality and employee productivity? The results revealed that $85 \%$ of the respondents said yes and $15 \%$ of the respondents said no (see Figure 2).

Furthermore, the existing literature indicates that e-HRM aims to improve organization performance by enhancing HR service quality, reducing costs, improving the decision making and reducing unnecessary activities. These aspects affect directly employee productivity (Morsy and El Demerdash, 2017). Similarity, Yusoff et al. (2010) reported that e-HRM is considered a new phenomenon which seeks to improve the quality and performance of HR. The adaptation of e-HRM in the tourism and hospitality industry will increase the effectiveness of HRM practices and performance (Morsy and El Demerdash, 2017; Pandey and Kumar, 2017). 
Figure 2: e-HRM practices and hotel performance

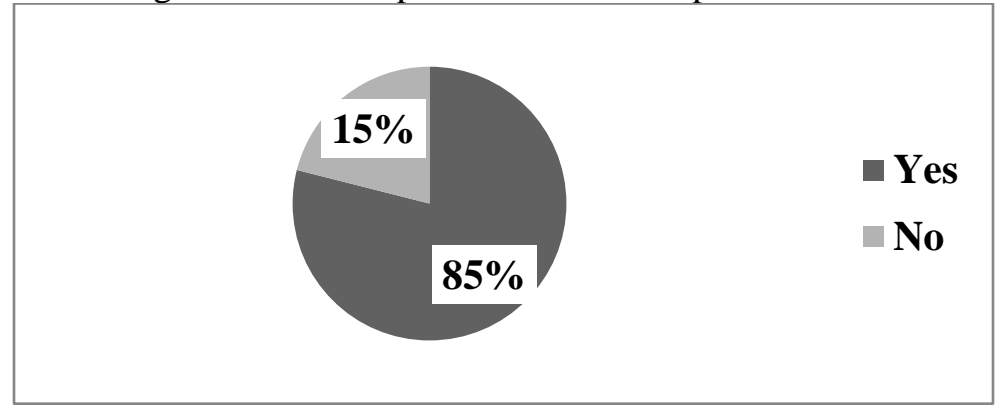

\section{Testing research hypotheses}

The conceptual model developed in this research includes several independent and dependent variables. The independent variables are operational, relational and transformational e-HRM. The dependent variables are: HRM service quality and employee productivity. Regression Analysis (see Table 6 and Figure 3) show that the constant coefficient $B=0.322$, Sig. $=0.001$ for operational e-HRM, $B=0.219$, Sig. $=0.004$ for relational e-HRM and $B=0.136$, Sig. $=0.002$ for transformational e-HRM, a significant level lower than (0.05), referring to the effect of operational e-HRM $(\mathrm{H} 1)$, relational e-HRM $(\mathrm{H} 2)$ and transformational e-HRM $(\mathrm{H} 3)$ on HR service quality. Additionally, the percentage of the determination coefficient $\left(\mathrm{R}^{2}\right)$ was $77 \%$ for eHRM practices (operational, relational and transformational e-HRM). This means that there is a strong impact of the independent variable (operational, relational and transformational e-HRM) on the dependent variable (HR service quality), which in turn mean the changes that occur in the dependent variable are influenced by the independent variable.

Therefore, the results revealed that there are statistically significant effects of operational, relational and transformational e-HRM on HRM service quality. The study rejected the null hypothesis and accepted the alternative ones $(\mathrm{H} 1, \mathrm{H} 2$ and $\mathrm{H} 3)$, which argued that there are significant effects of operational, relational and transformational e-HRM on HRM service quality.

Additionally, the study used a Multiple Regression Analysis in order to measure the effect of operational, relational and transformational e-HRM on employee productivity. Table (6) shows the constant coefficient $B=2.132$, Sig. $=0.015$ for operational e-HRM, $B=1.023$, Sig. $=0.003$ for relational e-HRM and $B=2.077$, Sig. $=0.001$ for transformational e-HRM, a significant level lower than (0.05). These indicate an effect on operational e-HRM (H4), relational e-HRM (H5) and transformational e-HRM (H6) on employee productivity. Additionally, the percentage of the determination coefficient $\left(\mathrm{R}^{2}\right)$ was $69 \%$ for e-HRM practices (operational, relational and transformational e-HRM). This means that there is a significant impact of the independent variables (operational, relational and transformational e-HRM) on the dependent variable (employee productivity) see Figure 3.

Therefore, the results of the current study revealed that there are statistically significant effects of operational, relational and transformational e-HRM on employee productivity. Therefore, this study rejected the null hypothesis and accepts the alternative ones (H4, H5 and H6), which claim that there are significant effects of operational, relational and transformational e-HRM on employee productivity.

Table 6: Multiple regression analysis

\begin{tabular}{|c|l|c|c|c|c|c|c|}
\hline \multicolumn{2}{|c|}{ Model } & \multicolumn{2}{|c|}{$\begin{array}{c}\text { Unstandardized } \\
\text { Coefficients }\end{array}$} & \multirow{2}{*}{$\begin{array}{c}* \\
\text { Sig. }\end{array}$} & \multirow{2}{*}{$\mathbf{R}^{2}$} & \multirow{2}{*}{ Dependent Variable } \\
\cline { 3 - 6 } & B & Std. Error & & & \\
\hline 1 & (Constant) & 1.465 & 0.436 & 5.243 & 0.000 & 0.772 & HRM service quality \\
\hline
\end{tabular}




\begin{tabular}{|c|c|c|c|c|c|c|c|}
\hline \multirow{2}{*}{\multicolumn{2}{|c|}{ Model }} & \multicolumn{2}{|c|}{$\begin{array}{l}\text { Unstandardized } \\
\text { Coefficients }\end{array}$} & \multirow{2}{*}{$\mathbf{t}$} & \multirow{2}{*}{$\begin{array}{c}* \\
\text { Sig. }\end{array}$} & \multirow[t]{2}{*}{$\mathbf{R}^{2}$} & \multirow{2}{*}{ Dependent Variable } \\
\hline & & B & Std. Error & & & & \\
\hline & Operational e-HRM & 0.322 & 0.110 & 2.542 & 0.001 & & \\
\hline & Relational e-HRM & 0.219 & 0.066 & 3.351 & 0.004 & & \\
\hline & Transformational e-HRM & 0.136 & 0.093 & 4.610 & 0.002 & & \\
\hline \multirow[t]{4}{*}{2} & (Constant) & 1.354 & 0.623 & 6.321 & 0.013 & \multirow[t]{4}{*}{0.690} & \multirow[t]{4}{*}{ Employee productivity } \\
\hline & Operational e-HRM & 2.132 & 0.073 & 5.621 & 0.015 & & \\
\hline & Relational e-HRM & 1.023 & 0.065 & 4.563 & 0.003 & & \\
\hline & Transformational e-HRM & 2.077 & 0.071 & 2.435 & 0.001 & & \\
\hline \multirow[t]{3}{*}{3} & (Constant) & 1.463 & 0.365 & 6.423 & 0.012 & \multirow[t]{3}{*}{0.820} & \multirow[t]{3}{*}{ Hotel performance } \\
\hline & HRM service quality & 2.072 & 0.076 & 4.782 & 0.006 & & \\
\hline & Employee productivity & 2.123 & 0.086 & 3.542 & 0.001 & & \\
\hline
\end{tabular}

* Significant level at 0.05

All in all, the current study used HR service quality and employee productivity as a moderator variable to identify the effect of e-HRM practices on hotel performance by measuring the service quality of HR and employee productivity. The results in Table 6 and figure 3 show the constant coefficient $B=2.072$, Sig. $=0.006$ for HRM service quality and $B=2.123$, Sig. $=0.001$ for employee productivity. Also, the percentage of the determination coefficient $\mathrm{R}^{2}$ was $82 \%$ for HRM service quality and employee productivity, meaning that there is a strong impact of the moderator variable (HRM service quality and employee productivity) on the dependent variable (hotel performance). Therefore, the result shows a statistically significant effect of HRM service quality and employee productivity on hotel performance, which in turn means the current study rejects the null hypothesis and accepts the alternative one $(\mathrm{H} 7)$, which claims that there are significant effects of HRM service quality and employee productivity on hotel performance.

Furthermore, the practices of e-HRM help to improve employee productivity and competences, reduce costs of staffing, and other costs (Sareen and Subramanian, 2012). Moreover, e-HRM enhances the communication between the employees, the customer and improves the workflow (Iqbal et al., 2019). Additionally, e-HRM implementations help the hotel industry improve their reputation and achieve a competitive advantage (Choochote and Chochiang, 2015).

Figure 3: Study hypotheses testing model

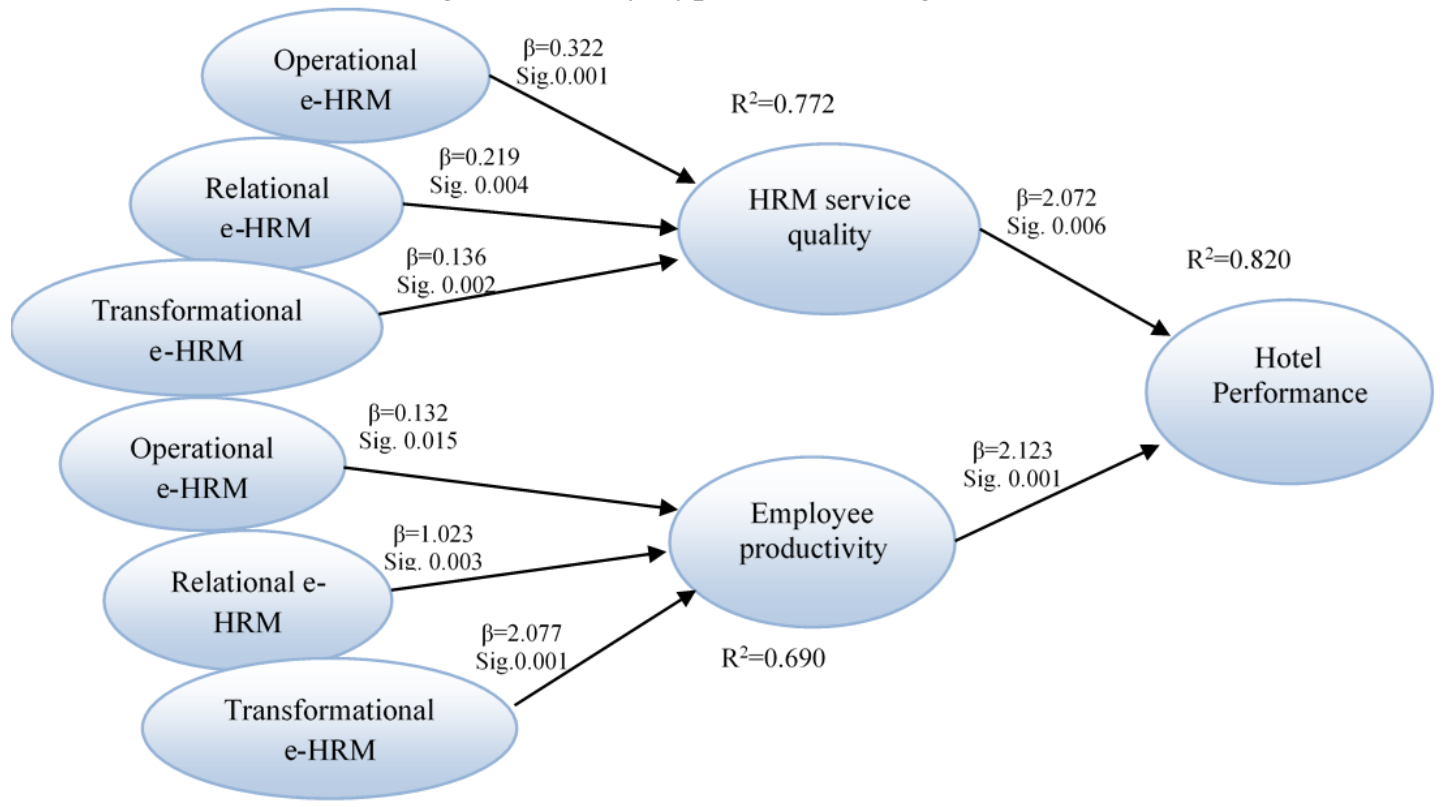




\section{Conclusions}

The current study collected data on e-HRM use in the hotel industry, contributing to the existing literature on the topic of e-HRM. It also shows the importance and benefits of e-HRM application in Five-star hotels in Cairo. The results indicate the support of the participants for eHRM practices in Five-star hotels. The findings showed the importance of e-HRM practices (operational, relational, and transformational) in improving the service quality of human resources.

Also, the study results indicated that e-HRM practices (operational, relational, and transformational) have a positive effect on employee productivity. Furthermore, the results showed that e-HRM affect the hotel performance by improving HR service quality and employee productivity. In addition, this study rejected the null hypothesis and accepted the alternative ones for all study hypotheses, which claimed that there are significant effects of e-HRM practices on hotel performance.

\section{Limitations and future research}

The current study has some limitations for instance: the main limitation of this study is getting access to the primary sources of data is not easy, but it is very difficult and challenging matter. The researcher found some challenges during data collection was the study participants were very busy and they did not have times, nobody wants to talk and said anything, or they would fear that the information gained may be used for official purposes. This study only includes data gathered on e-HRM practices in Five-star hotels in Cairo, therefore the results might not fully reflect e-HRM in other Egyptian Five-star hotels. Therefore, future research should address more hotels in Egypt; it also should undertake to test the findings of this study.

\section{References}

Agarwal, S., \& Lenka, U. (2018). Managing Organization Effectiveness Through E-Human Resource Management Tool-E-Learning: Indian Cases A Qualitative Approach. PEOPLE: International Journal of Social Sciences, 4(1), 289-312.

Ahmad, M., \& Allen, M. (2015). High-performance HRM and establishment performance in Pakistan: an empirical analysis. Employee Relations.

Al Hrou, S. A., \& Mohamed, B. (2014). Human resource management practice tourism and hotel industry. In SHS Web of Conferences (vol. 12, p. 01076). EDP Sciences.

Al Mamun, M. A., \& Islam, M. S. (2016). Perception of management on outcomes of human resource information system (HRIS). International Journal of Business and Social Research, 6(2).29-37.

Al-Ajlouni, M. I., Nawafleh, S., \& Alsari, H. (2019). The moderating effect of electronic-HRM on training and employee performance relationship: a moderated model. International Journal of Management Practice, 12(4), 511-532.

Ali, I. (2017). Effectiveness of EHRM on the Organizations' Performance Applied to Egyptian Tourism Authority. International Journal of Heritage, Tourism, and Hospitality, 11(2/2), $125-124$

Bagri, S. C., Babu, S., \& Kukreti, M. (2010). Human resource practices in hotels: A study from the tourist state of Uttrakhand, India. Journal of Human Resources in Hospitality \& Tourism, 9(3), 286-299.

Bissola, R., \& Imperatori, B. (2013). Facing e-HRM: the consequences on employee attitude towards the organisation and the HR department in Italian SMEs. European Journal of International Management, 7(4), 450-468. 
Choochote, K., \& Chochiang, K. (2015). Electronic human resource management (e-hrm) of hotel business in Phuket. International Journal of Advanced Computer Science and Applications, 6(4), 73-78.

Chuang, S. H., \& Lin, H. N. (2017). Performance implications of information-value offering in eservice systems: Examining the resource-based perspective and innovation strategy. The Journal of Strategic Information Systems, 26(1), 22-38.

EHA. (2019). Egyptian hotel association. Available at: http://www.egyptianhotels.org/. (Accessed 10/04/2019)

Foiji, M. H., Hoque, M. A., \& Khan, M. B. H. (2019). Strategic Potential of e-HRM in Outsourcing HR Functions. International Journal of Business and Social Research, 9(2), 01-10.

Francis, H., \& Baum, T. (2018). HR transformation within the hotel industry: building capacity for change. Worldwide Hospitality and Tourism Themes, 10(1), 86-100.

Iqbal, N., Ahmad, M., Raziq, M. M., \& Mendes Borini, F. (2019). Linking e-hrm practices and organizational outcomes: empirical analysis of line manager's perception. Revista Brasileira de Gestão de Negócios, 21(1), 48-69.

L'Écuyer, F., Raymond, L., Fabi, B., \& Uwizeyemungu, S. (2019). Strategic alignment of IT and human resources: Testing a mediation model of e-HRM in manufacturing SMEs Employee Relations, 41(5), 830-850.

Mahfod, J., \& Khalifa, N. Y. (2017). Electronic human resource management (E-HRM) system.

Marler, J. H., \& Parry, E. (2016). Human resource management, strategic involvement and eHRM technology. The International Journal of Human Resource Management, 27(19), 2233-2253.

Morsy, N., \& El Demerdash, J. M. (2017). Investigating the potential use of E-HRM: the Context of Egyptian Hotels and Travel Agents. Journal of Tourism Research, 16(1), 81-86.

Olivas-Lujan, M. R., Ramirez, J., \& Zapata-Cantu, L. (2007). e-HRM in Mexico: adapting innovations for global competitiveness. International Journal of Manpower, 28(5), 418434.

Pandey, A., \& Kumar, M. S. S (2017). A Study on E-HRM Practices in Hotel Industry in New Delhi. Vindhya International Journal of Management \& Research (VIJMR), 3(1), 23952059.

Rad, K. G., \& Kim, S. Y. (2018). Factors affecting construction labor productivity: Iran case study. Iranian Journal of Science and Technology, Transactions of Civil Engineering, 42(2), 165-180.

Rajalakshmi, M., \& Gomathi, S. (2016). A review on E-HRM: Electronic human resource management. Indian Journal of Research, 5(8), 364-379.

Ramezen, M., Nazari, Y., \& Ahmadi, M. M. (2013). The effect of electronic human resources management on quality of services provided by human resources in the insurance industry (case study: Iran Insurance Company in Khorramabad City). Journal of Social Issues \& Humanities, 1(7), 223-232.

Ruel, H. J., Bondarouk, T. V., \& Van der Velde, M. (2007). The contribution of e-HRM to HRM effectiveness: Results from a quantitative study in a Dutch Ministry. Employee relations, 29(3), 280-291.

Sareen, P., \& Subramanian, K. V. (2012). e-HRM: A strategic reveiw. International Journal of Human Resource Studies, 2(3), 119-127.

Saunders, M., Lewis, P. and Thornhill, A. (2012), Research Methods for Business Students, Pearson, Harlow. 
Stone, D. L., Lukaszewski, K. M., Stone-Romero, E. F., \& Johnson, T. L. (2013). Factors affecting the effectiveness and acceptance of electronic selection systems. Human Resource Management Review, 23(1), 50-70.

Wahyudi, E., \& Park, S. M. (2014). Unveiling the value creation process of electronic human resource management: An Indonesian case. Public Personnel Management, 43(1), 83117.

Yusoff, Y. M., Ramayah, T., \& Ibrahim, H. (2010). E-HRM: A proposed model based on technology acceptance model. African Journal of Business Management, 4(14), 30393045. 